\title{
Revealed Comparative Advantage and Competitiveness for RMG Industry of Bangladesh: A Pre and Post US- GSP Suspension Analysis
}

\author{
Ayub Ali, Rashedul Kabir*, Samim Uddin \\ Department of Research \& Development, Bangladesh Knitwear Manufacturers Exporters Association-BKMEA, Dhaka, Bangladesh \\ Email address: \\ rkshimu181@gmail.com (R. Kabir) \\ ${ }^{*}$ Corresponding author
}

\section{To cite this article:}

Ayub Ali, Rashedul Kabir, Samim Uddin. Revealed Comparative Advantage and Competitiveness for RMG Industry of Bangladesh: A Pre and Post US- GSP Suspension Analysis. International Journal of Sustainable Development Research. Vol. 3, No. 6, 2017 , pp. 54-62. doi: 10.11648/j.jijsdr.20170306.11

Received: October 2, 2017; Accepted: October 30, 2017; Published: November 15, 2017

\begin{abstract}
This study investigates the Revealed Comparative Advantage (RCA) analysis for the ready-made garments (RMG) exports of Bangladesh and major competing countries i.e. India, Sri Lanka, Vietnam, Pakistan, China, Cambodia and Turkey. The purpose is to explore the impact assessment on the US-GSP suspension for Bangladesh as well as how US-GSP suspension influences Bangladesh's manufacturing sectors and export of RMG goods. The RCA analyzes the extent of export competition between Bangladesh and its major competitors. For this reason, the study applies the Balassa Index. It argues that the degree of competition among major competitors intensifies with the implementation of the US-GSP requirements to get the GSP facilities to US market. After the suspension of the US-GSP, Bangladesh's export share in the US market decreased from 6.01 to 5.68 percent in 2014, amounting US\$ 134.64 million. For the other destination, the EU-market share is remained steady for Bangladesh's RMG exports. This indicates that the US-GSP status is important to enhance the positive image and increase trade volume of the world market. This paper contributes to the literature by investigating whether the US-GSP has any significant influence on the trade flow of Bangladesh. This study explores Bangladesh's comparative advantage in the top ten RMG products amongst the major competing countries. Further, it also analyzes the RCA for the US and EU markets covering the pre and post US-GSP suspension periods and concludes that Bangladesh had a greater comparative advantage in the EU market compared to the US market than its competitors for the top ten RMG products during the period covering 2012 to 2015.
\end{abstract}

Keywords: Revealed Comparative Advantage, Balassa Index, Generalized System of Preferences, Ready-Made Garment, Trade Openness, Bangladesh

\section{Introduction}

Comparative advantage is necessary for a country or a group of countries or regional bloc to scrutinize all sorts of benefits from international trade. Liesner (1958) first introduced the concept of Revealed Comparative Advantage (RCA), which is to assess how competitive the country is in exporting a certain product as compared to the world [1]. Later, Balassa (1965) developed it further. Balassa (1965; 1971 ; 1977) published and finally analyzed RCA technique for manufacturing sectors and across industries. Comparative advantage in trade increases the efficiency of using scarce resources and promotes higher economic welfare [2], [3], [4].
RCA measurement can efficiently be used to determine comparative advantage in trade such as patterns of trade specialization, trade patterns and international trade advantage. The Heckscher-Ohlin theory states that a country's comparative advantage depends on relative factor endowment across nations and trade affects relative factor prices within and across nations [5], [6]. The United States (US) and the European Union (EU) are the two of the largest Ready-Made Garments (Here, RMG consists of Bangladesh's top ten exporting knitwear (Harmonized System-HS 61) and woven wear (HS-62) products exports earning markets for 
Bangladesh. Bangladesh is the second largest exporter to both the US and EU market.

Generalized System of Preferences (GSP) which provides opportunities for many of the world's developing and underdeveloped countries to use trade privileges such as zero tariffs to grow their economies and climb out of poverty. On 11 August 2015, The US declared GSP facilities on 5,000 products for 122 counties, excluding Bangladesh and Russia. There is a little doubt that the US-GSP (Generalized System of Preference in the United States) status bears a positive image for the RMG sector of Bangladesh. However, the negative impact of the US-GSP suspension for Bangladesh is speculated as a warning for future trade flow between Bangladesh and the US, including the prospect of retaining the Most Favored Nation (MFN-A status or level of treatment accorded by one state to another in international trade) status, which would benefit Bangladesh's economic growth. According to the Bangladesh Economic Review (2014) during the last three years, there was no Foreign Direct Investment (FDI) inflow from the United States to Bangladesh. In such circumstances, a repeated attempt by the Bangladeshi Government to regain the US-GSP is crucial for the nation's continued economic growth [7].

At present, Bangladesh is facing threats from the major competitors of RMG exports in the world, particularly China, India, Pakistan, Sri Lanka, Vietnam and Cambodia. This study analyzes competitive advantage of the RMG sector by using the RCA Balassa Index (1965), at Harmonized System (HS) 6 -digit level. It aims to present a relative position of the RMG exports of Bangladesh in the world markets and compare its comparative advantage against the pre and postsuspension of the US-GSP with major competitors in the US and EU markets.

\section{Overview of Bangladesh's Export Trends}

Bangladesh is renowned for its garments products around the world. This largest exporting industry of Bangladesh has been boosting the economy for the last two decades. According to the Annual Report of Bangladesh Bank in the FY-2013-14, the macroeconomic situation in Bangladesh has been quite stable for recent few years. Export earnings from the RMG industries and remittance inflows help to achieve the solid economic growth rate, where the RMG sector alone contributes $14.09 \%$ of the total GDP [8]. The RMG sector plays a key role in employment generation and income earning particularly for the poor. Nearly 4.5 million workers (directly) and more than 15 million inhabitants are indirectly associated with the RMG industry in Bangladesh. RMG is a manufacturing-based industry, and Bangladesh is the second largest RMG producer now in the world. As Bangladesh is one of the cheapest garments producing countries due to cheaper labour supply, the foremost emphasis has been given by the successive governments to the development of this sector for reaping the benefits of the abundant availability of its cheaper labour force. At present, there are about 5 thousand RMG factories running in full production in the country. The RMG sector's total export earning was USD 28.09 billion in 2015, 14.7 percent higher than the previous year. The contribution by the RMG sector in the national export earning was $81.16 \%$ in 2014. Table 1 shows the current picture of Bangladesh's RMG's export share to the world, USA and European (EU) trade bloc.

Table 1. Bangladesh's RMG Market Share in the World, USA and EU Markets.

\begin{tabular}{|c|c|c|c|c|c|c|c|c|c|c|c|}
\hline Destination & 2005 & 2006 & 2007 & 2008 & 2009 & 2010 & 2011 & 2012 & 2013 & 2014 & 2015 \\
\hline World (\%) & 2.54 & 2.72 & 2.73 & 3.31 & 3.89 & 4.27 & 4.70 & 5.66 & 5.99 & 6.17 & 6.83 \\
\hline USA (\%) & 3.27 & 3.91 & 4.02 & 4.66 & 5.25 & 5.37 & 5.60 & 5.60 & 6.01 & 5.68 & 6.12 \\
\hline EU (\%) & 4.20 & 5.09 & 4.73 & 5.15 & 5.94 & 6.54 & 7.81 & 8.76 & 9.49 & 9.89 & 11.06 \\
\hline
\end{tabular}

Source: ITC, Geneva, 2016

Table 1 shows the present situation of Bangladesh's RMG export share in the world trade as well as in the US market and EU trade bloc. The growth of RMG export is 2.50 percentage points between the year 2010 and 2015 for Bangladesh in the world market. The US RMG market is one of the largest export destinations for Bangladesh. Bangladesh's RMG products gradually increased until the suspension of the US - GSP from the year 2010. After the suspension of the US - GSP, the share of US market decreased from 6.01 to 5.68 percent in the year 2014, which accounted for USD 134.64 million. On the other hand, Bangladesh's RMG has gradually been making a positive trend in the market share in the EU market. Therefore, the US- GSP status is important to enhance the positive image, as well as to increase trade volume in the world market.
The ratio of a country's total trade, the sum of exports plus imports, to its gross domestic product (GDP) is termed as trade openness. Figure 1 depicts the annual trade openness for the competing countries (China, India, Sri- Lanka, Vietnam, Pakistan, Cambodia and Turkey) for Bangladesh. This figure points out that Bangladesh's trade openness is correlated with the world economy. From 2001 to 2008, its trade has produced a positive trend and conversely after the global economic recession period (2008-2010) the trade openness has gradually been decreasing. However, at present, the US-GSP suspension status has made tardy Bangladesh's RMG trade comparing with the competitors' countries. Bangladesh's trade openness is also at the third position from the below in 2015 amongst the competitors. 


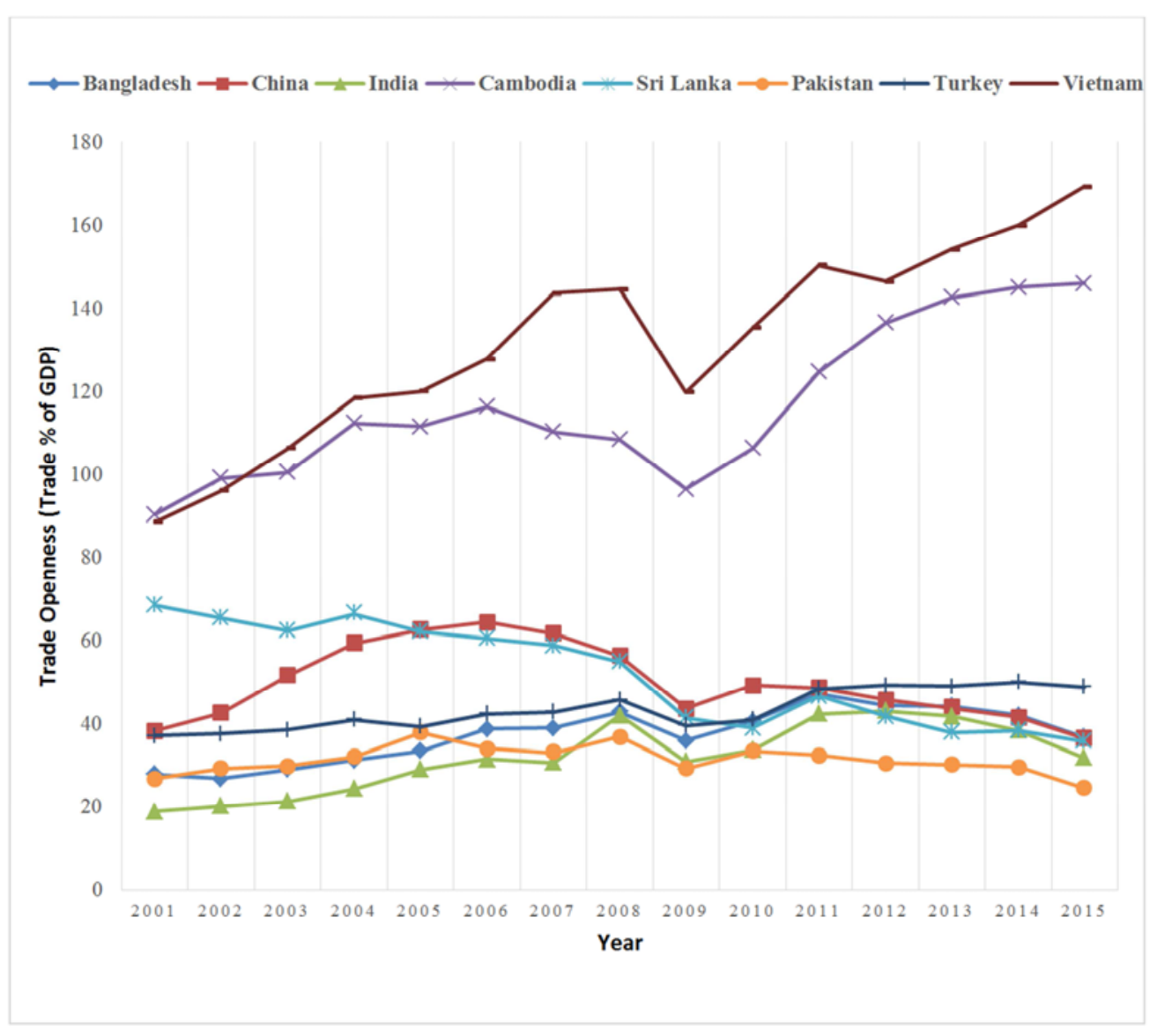

Source: World Bank Group, 2016

Figure 1. Trade Openness of the Major Competitor Countries.

\section{Objective of the Study}

The goal of this study is to analyze the comparative advantage and competitiveness for the RMG sector of Bangladesh over its other major competitors. Thus the study attempts to verify the RCA status for the pre and post of USA-GSP suspension.

To achieve this goal, the following specific objectives are identified for this study: a) to analyze Bangladesh's export trends, specially woven and knitwear; b) to make comparative trade analysis of RMG industry of Bangladesh with its major competitors during the pre and post the USGSP suspension and c) to show the trend of trade of RMG industry of Bangladesh and other competing countries.

\section{Literature Review}

RCA index is an important investigative instrument for comparative advantage over time. It provides information on the top competitor countries on trade movement in comparative advantage term over a given period. Many studies are found to use the concept of RCA by using export data. Balassa (1977) examined the pattern of comparative advantage for various countries for the period from 1953 to 1971 [4]. The evidence supported that research-intensive products, keep product cycle continue when those are traded. This study also measured the standard deviation of RCA indices to see the correlations between size and exports diversification for various countries. Yeats (1992) examined the trade pattern and concluded that distortion in trade patterns due to inequitable trade barriers were features of RTAs [9].

Ahmad (2013) estimated RCA of textile and clothing sectors of Pakistan. It revealed that Pakistan has a comparative advantage in the textile sector, but the low comparative advantage in the clothing sector. The study also analyzed RCA of textile and clothing (Textile is a fabric that is knitted or woven and made from yarn. Clothing is the readymade garment that is made from the textile products) sectors during (1995 to 2005) the period of pre and post quota imposition by importing countries [10]. Shohibul (2013) investigated the comparative advantage for the ASEAN countries and China by using a Revealed Symmetric Comparative Advantage (RSCA) and Trade Balance Index (TBI) approach. Export products are analyzed based on Standard International Trade Classification (SITC) revision3. The study disclosed that the China has more established patterns of trade, while ASEAN trade patterns are dynamic [6].

Bastos and Cabral (2007) tested the dynamics of 
international trade patterns in 20 OECD countries over the period covering 1980 to 2000 . They observed the changes in trade patterns explained by an initial endowment of human capital and industry-specific changes in labour productivity and labour cost. Trade liberalization induced an increase in the previous specialization of larger OECD economies in industries with increasing the return to scale [11]. Similarly, Hadzhiev (2014) measured overall RCA for all goods or Euclidean distance by specialization in export. The approach provides empirical evidence for the theoretically proven scale and scope effect in the area of trade and specialization of exports. The study also explained that the overall revealed comparative advantages approach is a useful tool for the analysis of export specialization in modern international trade [12].

Lalit (2013) calculated RCA of export performance of clothing sector for India and Bangladesh. The study used the Harmonized System (HS up to 4 -digit level) to analyze competitive advantage of various clothing products for the period of 1995 to 2003 for both countries. Furthermore, it revealed that comparative advantage in clothing products of India increased from 23 products to 25 products and comparative advantage of the same products of Bangladesh increased from 21 to products to 29 products in this period [13].

\section{Data Sources and Methodology}

This study considered Revealed Comparative Advantage (RCA) Balassa Index for RMG industry and major competitors of Bangladesh separately. For this purpose, the data have been collected from International Trade Centre (ITC) Map, Geneva for variables of RCA index. RCA index is a standard approach to calculate a country's comparative advantage or comparative disadvantage in commodities, industries or sectors.

This study applies the RCA index to address the comparative advantage of the major competitor countries of Bangladesh in the USA and EU market instead. The following formula is used based on the Balassa Index [2], [3], [4]:

$$
R C A=\frac{\frac{x_{i j}}{x_{i}}}{\frac{x_{s j}}{x_{s}}}
$$

Where,

$\mathrm{X}_{\mathrm{ij}}: \mathrm{i}^{\text {th }}$ the country's export of commodity $\mathrm{j}$ to the USA and European Union markets

$\mathrm{X}_{\mathrm{i}}: \mathrm{i}^{\text {th }}$ the country's total export to the USA and European Union markets

$\mathrm{Xs}_{\mathrm{j}}$ : The major competing countries' exports of commodity $\mathrm{j}$ to the USA and

European Union markets

$\mathrm{X}_{\mathrm{S}}$ : The major competing countries' total exports to the USA and the European Union

Markets

According to the value of this index, if $\mathrm{RCA}>1$, then a country has a comparative advantage; and if $\mathrm{RCA}<1$, then a country has a comparative disadvantage in that commodity or industry. By using the Balassa index, the study attempts to calculate the RCA for the period before and after US - GSP suspension.

To visualize systematically, Normalized RCA or NRCA has been calculated to explore the country's export performance of those commodities. The NRCA index range is between -1 and +1 which is now bound to systematic and also allows comparative advantages across time, countries and sectors. Hence, NRCA positive values indicate comparative advantages, while any negative value shows trade disadvantage of the respective products of those countries.

In order to analyze the impacts of the suspension of US GSP within countries and regions, NRCA index has calculated using the simple normalization proposed by Laursen (2000) [14], [15]. The normalized RCA index, NRCA, becomes:

$$
\text { Normalized RCA or NRCA }=\frac{\mathrm{RCA}-1}{\mathrm{RCA}+1}
$$

\section{Bangladesh, the US and EU Trade Relationship}

The relationship between Bangladesh and the US had not been flourished when Britain was in power in the Indian Subcontinent. At the time of the liberation war, the Nixon administration sided with Pakistan. However, after the liberation of Bangladesh, the USA has changed its position towards Bangladesh. The first opinion change came when the US, on 4 April 1972, recognized Bangladesh as an independent country and issued USD 300 million for food aid under Public Law 480 also known as "Food for Peace" by which US food can be used for Overseas Aid. The US embassy was later established in Bangladesh. At present, the relationship between the two countries has evolved into a "Three Dimensional (3D)" one- Democracy, Development and Denial of space for terrorism. In 2012, a strategic partnership agreement between the two countries was signed when the Secretary of State Hillary Clinton visited Dhaka. Bangladesh has garnered praise from high-level diplomats from the US, including President Barak Obama, Hillary Clinton, and Colin Powel for its MDG goals.

From an economic perspective, the US is the single largest RMG export-earning source of income for Bangladesh. The landmark of economic co-operation between the USA and Bangladesh was the consideration for incorporation in its GSP program. The US-GSP was launched in January 1976 under the Trade Act of 1774. Due to the overpopulated country, Bangladesh had to utilize this facility by expanding it labour-intensive sectors such as RMG, and agriculture. Export trends have seen growth positively under the duration of the GSP. Due to the GSP facilitation, Bangladesh could export to other countries outside the USA. Presently, the popularity of Bangladesh Knitwear and Woven clothing 
demonstrates that the country holds the second and third position respectively concerning the world export. It was a shock for Bangladesh factory workers when the decision to suspend GSP was made on June 27, 2013. The then President Barack Obama (2013) stated, "It has not taken or is not taking steps to afford internationally recognized worker rights to workers in the country". This was exemplified when in 2013 the Savar building (Rana Plaza) collapsed claiming more than thousands of lives. Bangladesh had to pay $15.3 \%$ taxes on exports to USA market between 2014 and 2015. Due to the limited export basket, RMG covers more than $82 \%$ of national export.

Bangladesh expects to regain the GSP consideration by the USA in the future even though the economic cost of the GSP being suspended is not significant. There is a fear due to its influence on the EU market which may decide to withdraw GSP privilege to Bangladesh. The message of hope, which the EU speaks about, has its advantages under GSP since 1971. Most of the RMG products have been included in this program. As an economic community, the EU and Bangladesh forged an economic relationship in 1973. The diplomatic relationship between the European Commission and Bangladesh was first introduced in 1982. The European Commission began its full-fledged delegation in Bangladesh in 1989. Bangladesh got the maximum level of cooperation from the EU and successfully complyed the Commercial CoOperation Agreement in 1976 and the National Indicative Program (2003- 2005). Bangladesh still enjoys the maximum benefits as a part of the Least Developed Countries (LDCs). The European Union imports more than $60 \%$ of the total RMG exports from Bangladesh annually.

Bangladesh as an LDC gets some privileges from the EU as follows:

a) Being the largest trading partner of Bangladesh including having duty free market access under Everything But Arms (EBA) initiative

b) Development partner issuing project aid for social developments like MDGs

c) Democratic supporter

d) Climate change related co-operation, etc.

Those indicate a high level of co-operation between the EU and Bangladesh. Bangladesh and the EU jointly incepted a commission that began from 2001. The EU has offered GSP for 179 LDCs and developing countries for about 7200 products covering their $66 \%$ of tariff lines. Even after the formation of the EU in 1993, the EU has continued with this scheme. In 2003, the EU revised the GSP where Bangladesh has got the final stage rules of origin for RMG products and facility of EBA incentive as LDCs.

\section{Results and Discussion}

Bangladesh is the second largest RMGs exporter in the world. This sector thus plays a key role in employment generation and for income generation to the poor community in the country. About 4.5 million workers are directly and more than 15 million inhabitants are indirectly associated with the RMG sector of Bangladesh. Its RMG market is a volatile market that everyday fluctuates against that of the competing countries as well as achieving the extra facilities. Hence, this paper tries to measure and assess the competitive advantages of the top ten RMG products of Bangladesh to explore its trade potential in this sector. Finally, an empirical analysis of the pre and post US-GSP suspension has been analyzed by measuring the Raveled Comparative Advantage and competitiveness for its RMG industry.

\subsection{Top 10 Bangladeshi RMG Exporting Products Analysis}

The Analysis has focused on the top ten RMG products of Bangladesh by using an explanation of RCA analysis as well as major countries' RCA explains aligned with Bangladesh's top ten RMG products. This RCA index is provided for eight countries over the period $2012-2016$ at HS - 6-digit level. Table 2 below reports a brief summary of the products.

Table 2. Bangladesh's Top Ten (10) RMG Exporting Products.

\begin{tabular}{ll}
\hline HS-Code & Product-label \\
\hline 610910 & T-shirts, cotton \\
620342 & Men's or boys' trousers \\
620462 & Women's or girls' trousers \\
611020 & Jerseys, pullovers, cardigans, waistcoats, cotton \\
611030 & Jerseys, pullovers, cardigans, waistcoats, man-made fibres \\
620520 & Men's or boys' shirts of cotton \\
610462 & Women's or girls' trousers, knitted \\
610510 & Men's or boys' shirts of cotton, knitted \\
611120 & Babies' garments \\
610990 & T-shirts, textile materials \\
\hline
\end{tabular}

Source: According to ITC ranking, 2016

\subsection{Comparative Advantage of the Major Competitors in the USA-EU Market}

Ready Made Garments (RMG) markets in the US and EU are the largest markets for Bangladesh's RMG products. After the suspension of the US-GSP, RMG trade performance has been influenced by the competing countries and also by trade policies of the destination countries. The Balassa's Reveal Comparative Advantage (RCA) or Normalized Reveal Comparative Advantage (NRCA) indexes may vary with factor endowment ranks of the major competitors. Table 3 depicts the NRCA ranking information of major countries from 2012 to 2015 . According to the result, Bangladesh has the highest NRCA in the three products out of the top ten products, such as (610910), (620342), and (620462) from 2012 to 2015 respectively, compared to the other exporting countries in the US market. On the other hand, Cambodia has the highest NRCA for the five products out of the top ten RMG products, such as (611020), (620520), 610462, (611120) and (610990) from 2012 to 2015 respectively. Sri Lanka and Vietnam are the close competitors in the USA and EU markets. At the same time, Pakistan has the highest NRCA for two RMG products such as (611030) and (610510). 
Table 3. NRCA of Ten RMG Products of the Competitors in the US Market.

\begin{tabular}{|c|c|c|c|c|c|c|c|c|c|c|c|}
\hline Country & Year (2000) & 610910 & 620342 & 620462 & 611020 & 611030 & 620520 & 610462 & 610510 & 611120 & 610990 \\
\hline \multirow{4}{*}{ Bangladesh } & 12 & 0.97 & 0.95 & 0.89 & 0.60 & 0.89 & 0.54 & 0.69 & 0.81 & 0.65 & 0.45 \\
\hline & 13 & 0.97 & 0.96 & 0.89 & 0.63 & 0.89 & 0.61 & 0.69 & 0.82 & 0.67 & 0.43 \\
\hline & 14 & 0.97 & 0.96 & 0.91 & 0.67 & 0.91 & 0.63 & 0.68 & 0.84 & 0.72 & 0.50 \\
\hline & 15 & 0.97 & 0.96 & 0.91 & 0.71 & 0.91 & 0.66 & 0.73 & 0.80 & 0.77 & 0.51 \\
\hline \multirow{4}{*}{ India } & 12 & -0.31 & 0.20 & -0.42 & -0.03 & 0.41 & -0.69 & -0.04 & 0.53 & -0.67 & -0.38 \\
\hline & 13 & -0.39 & 0.21 & -0.40 & 0.02 & 0.36 & -0.65 & 0.01 & 0.56 & -0.58 & -0.38 \\
\hline & 14 & -0.38 & 0.16 & -0.43 & 0.03 & 0.42 & -0.67 & 0.10 & 0.57 & -0.47 & -0.29 \\
\hline & 15 & -0.37 & 0.23 & -0.41 & 0.10 & 0.50 & -0.72 & 0.13 & 0.61 & -0.45 & -0.35 \\
\hline \multirow{4}{*}{ Sri Lanka } & 12 & 0.82 & 0.85 & 0.80 & 0.60 & 0.31 & 0.76 & 0.47 & 0.79 & 0.93 & 0.73 \\
\hline & 13 & 0.81 & 0.83 & 0.79 & 0.63 & 0.42 & 0.74 & 0.60 & 0.79 & 0.92 & 0.79 \\
\hline & 14 & 0.82 & 0.84 & 0.81 & 0.67 & 0.52 & 0.74 & 0.67 & 0.81 & 0.90 & 0.85 \\
\hline & 15 & 0.81 & 0.85 & 0.79 & 0.66 & 0.53 & 0.78 & 0.70 & 0.83 & 0.91 & 0.88 \\
\hline \multirow{4}{*}{ Vietnam } & 12 & 0.82 & 0.85 & 0.80 & 0.60 & 0.31 & 0.76 & 0.47 & 0.79 & 0.93 & 0.73 \\
\hline & 13 & 0.81 & 0.83 & 0.79 & 0.63 & 0.42 & 0.74 & 0.60 & 0.79 & 0.92 & 0.79 \\
\hline & 14 & 0.82 & 0.84 & 0.81 & 0.67 & 0.52 & 0.74 & 0.67 & 0.81 & 0.90 & 0.85 \\
\hline & 15 & 0.81 & 0.85 & 0.79 & 0.66 & 0.53 & 0.78 & 0.70 & 0.83 & 0.91 & 0.88 \\
\hline \multirow{4}{*}{ Pakistan } & 12 & 0.76 & -0.06 & 0.75 & 0.77 & 0.91 & -0.49 & -0.02 & 0.95 & 0.76 & 0.17 \\
\hline & 13 & 0.76 & -0.18 & 0.76 & 0.76 & 0.92 & -0.35 & 0.16 & 0.93 & 0.73 & 0.23 \\
\hline & 14 & 0.76 & -0.01 & 0.79 & 0.78 & 0.91 & -0.25 & 0.23 & 0.94 & 0.76 & 0.23 \\
\hline & 15 & 0.79 & -0.01 & 0.79 & 0.77 & 0.91 & -0.31 & 0.09 & 0.94 & 0.69 & 0.09 \\
\hline \multirow{4}{*}{ China } & 12 & -0.86 & -0.80 & -0.61 & -0.49 & -0.81 & -0.25 & -0.38 & -0.88 & -0.79 & -0.44 \\
\hline & 13 & -0.86 & -0.81 & -0.62 & -0.49 & -0.82 & -0.31 & -0.49 & -0.87 & -0.76 & -0.43 \\
\hline & 14 & -0.86 & -0.83 & -0.65 & -0.51 & -0.83 & -0.28 & -0.57 & -0.89 & -0.72 & -0.46 \\
\hline & 15 & -0.87 & -0.84 & -0.66 & -0.54 & -0.85 & -0.36 & -0.61 & -0.89 & -0.73 & -0.54 \\
\hline \multirow{4}{*}{ Cambodia } & 12 & 0.85 & -0.10 & 0.83 & 0.89 & 0.90 & 0.86 & 0.88 & 0.87 & 0.96 & 0.92 \\
\hline & 13 & 0.84 & 0.09 & 0.80 & 0.87 & 0.89 & 0.88 & 0.92 & 0.85 & 0.95 & 0.90 \\
\hline & 14 & 0.83 & 0.01 & 0.82 & 0.87 & 0.90 & 0.86 & 0.94 & 0.87 & 0.94 & 0.86 \\
\hline & 15 & 0.79 & 0.01 & 0.80 & 0.86 & 0.88 & 0.87 & 0.94 & 0.87 & 0.93 & 0.89 \\
\hline \multirow{4}{*}{ Turkey } & 12 & -0.23 & 0.25 & -0.12 & -0.45 & 0.00 & -0.18 & -0.79 & -0.05 & -0.61 & 0.33 \\
\hline & 13 & -0.17 & 0.21 & -0.17 & -0.46 & 0.06 & -0.16 & -0.74 & -0.10 & -0.49 & 0.25 \\
\hline & 14 & -0.13 & 0.21 & -0.14 & -0.39 & 0.02 & -0.11 & -0.70 & -0.03 & -0.49 & 0.19 \\
\hline & 15 & -0.13 & 0.20 & -0.07 & -0.29 & 0.04 & 0.00 & -0.78 & -0.03 & -0.50 & 0.16 \\
\hline
\end{tabular}

Source: ITC, Geneva and Authors' own calculation, 2016

NRCA for the top 10 RMG products of these major competitors has been calculated in the context of US-GSP suspension. NRCA values in the EU market are very important to know about the possibility to increase the trade volume in the destination countries for the major competitor countries. This table (4) shows the NRCA which has been calculated for the US-GSP suspension period from 2012 to 2015 for Bangladesh, India, Sri Lanka, Vietnam, Pakistan, China, Cambodia and Turkey. The results presented in the table 4 clearly indicate that Bangladesh has a greater comparative advantage and stable NRCA during the phasing out of the US- GSP suspension period. After the US-GSP suspension for Bangladesh, the NRCA of two products (i.e. 611020 and 611030) has declined from 2012 to 2015, and at the same time, NRCA for RMG products of India has risen more than that of the other countries since China has the intention to give up RMG production. Therefore, Bangladesh, Cambodia, and Sri Lanka have achieved the first, second and third position respectively in NRCA in the EU market. 
Table 4. NRCA of Ten RMG Products of the Competitors in the EU Market.

\begin{tabular}{|c|c|c|c|c|c|c|c|c|c|c|c|}
\hline Country & Year (2000) & 610910 & 620342 & 620462 & 611020 & 611030 & 620520 & 610462 & 610510 & 611120 & 610990 \\
\hline \multirow{4}{*}{ Bangladesh } & 12 & 0.93 & 0.89 & 0.82 & 0.86 & 0.79 & 0.85 & 0.86 & 0.91 & 0.74 & 0.43 \\
\hline & 13 & 0.93 & 0.90 & 0.84 & 0.85 & 0.78 & 0.85 & 0.85 & 0.90 & 0.76 & 0.47 \\
\hline & 14 & 0.93 & 0.90 & 0.85 & 0.84 & 0.78 & 0.85 & 0.85 & 0.90 & 0.77 & 0.47 \\
\hline & 15 & 0.93 & 0.90 & 0.85 & 0.84 & 0.78 & 0.86 & 0.87 & 0.91 & 0.79 & 0.57 \\
\hline \multirow{4}{*}{ India } & 12 & 0.13 & -0.36 & -0.48 & -0.39 & -0.85 & 0.32 & -0.02 & 0.19 & 0.26 & -0.47 \\
\hline & 13 & 0.18 & -0.39 & -0.49 & -0.32 & -0.86 & 0.34 & 0.09 & 0.20 & 0.31 & -0.37 \\
\hline & 14 & 0.28 & -0.34 & -0.46 & -0.24 & -0.81 & 0.36 & 0.22 & 0.27 & 0.40 & -0.34 \\
\hline & 15 & 0.32 & -0.33 & -0.50 & -0.20 & -0.80 & 0.37 & 0.28 & 0.27 & 0.46 & -0.26 \\
\hline \multirow{4}{*}{ Sri Lanka } & 12 & 0.56 & 0.61 & 0.50 & -0.01 & 0.24 & 0.32 & 0.67 & 0.53 & 0.76 & 0.68 \\
\hline & 13 & 0.50 & 0.59 & 0.37 & 0.04 & 0.17 & 0.43 & 0.73 & 0.56 & 0.79 & 0.71 \\
\hline & 14 & 0.48 & 0.54 & 0.35 & 0.05 & 0.15 & 0.50 & 0.76 & 0.54 & 0.82 & 0.75 \\
\hline & 15 & 0.44 & 0.53 & 0.37 & 0.10 & 0.20 & 0.50 & 0.73 & 0.47 & 0.85 & 0.76 \\
\hline \multirow{4}{*}{ Vietnam } & 12 & -0.64 & -0.39 & -0.45 & -0.53 & -0.43 & 0.24 & -0.36 & -0.04 & -0.88 & -0.14 \\
\hline & 13 & -0.71 & -0.41 & -0.50 & -0.62 & -0.54 & 0.21 & -0.60 & -0.09 & -0.87 & -0.22 \\
\hline & 14 & -0.73 & -0.36 & -0.52 & -0.68 & -0.47 & 0.22 & -0.66 & -0.02 & -0.86 & -0.25 \\
\hline & 15 & -0.71 & -0.48 & -0.53 & -0.69 & -0.49 & 0.15 & -0.63 & 0.02 & -0.88 & -0.22 \\
\hline \multirow{4}{*}{ Pakistan } & 12 & -0.09 & 0.84 & 0.72 & 0.43 & -0.42 & -0.59 & 0.49 & 0.60 & -0.12 & 0.18 \\
\hline & 13 & -0.21 & 0.81 & 0.76 & 0.42 & -0.37 & -0.68 & 0.46 & 0.61 & -0.08 & -0.16 \\
\hline & 14 & -0.08 & 0.84 & 0.76 & 0.53 & -0.30 & -0.73 & 0.46 & 0.62 & -0.05 & -0.13 \\
\hline & 15 & 0.02 & 0.86 & 0.79 & 0.59 & -0.14 & -0.62 & 0.52 & 0.64 & 0.03 & -0.12 \\
\hline \multirow{4}{*}{ China } & 12 & -0.85 & -0.71 & -0.55 & -0.46 & -0.24 & -0.65 & -0.66 & -0.74 & -0.27 & -0.63 \\
\hline & 13 & -0.86 & -0.74 & -0.62 & -0.47 & -0.22 & -0.68 & -0.68 & -0.75 & -0.34 & -0.61 \\
\hline & 14 & -0.88 & -0.78 & -0.67 & -0.51 & -0.26 & -0.71 & -0.72 & -0.80 & -0.43 & -0.64 \\
\hline & 15 & -0.89 & -0.81 & -0.70 & -0.53 & -0.31 & -0.73 & -0.74 & -0.80 & -0.48 & -0.65 \\
\hline \multirow{4}{*}{ Cambodia } & 12 & 0.65 & 0.62 & 0.68 & 0.82 & 0.84 & 0.47 & 0.85 & 0.68 & 0.56 & 0.78 \\
\hline & 13 & 0.57 & 0.69 & 0.70 & 0.81 & 0.81 & 0.52 & 0.85 & 0.63 & 0.55 & 0.77 \\
\hline & 14 & 0.59 & 0.69 & 0.68 & 0.79 & 0.81 & 0.60 & 0.85 & 0.55 & 0.59 & 0.81 \\
\hline & 15 & 0.56 & 0.66 & 0.75 & 0.78 & 0.81 & 0.60 & 0.86 & 0.40 & 0.54 & 0.81 \\
\hline \multirow{4}{*}{ Turkey } & 12 & 0.42 & 0.26 & 0.39 & 0.09 & 0.04 & 0.18 & 0.28 & 0.08 & -0.39 & 0.71 \\
\hline & 13 & 0.37 & 0.24 & 0.39 & 0.10 & 0.03 & 0.15 & 0.22 & 0.05 & -0.40 & 0.67 \\
\hline & 14 & 0.33 & 0.21 & 0.40 & 0.11 & 0.01 & 0.18 & 0.17 & 0.10 & -0.37 & 0.67 \\
\hline & 15 & 0.27 & 0.18 & 0.38 & 0.09 & 0.04 & 0.18 & -0.03 & 0.02 & -0.44 & 0.62 \\
\hline
\end{tabular}

Source: ITC, Geneva and Authors' own calculation, 2016

\subsection{Analysis of Overall Comparative Advantages for Competitors Countries}

Being an export-oriented country, Bangladesh largely depends on the Ready Made Garment (RMG) exports for its export earnings. The share of Bangladesh in the global RMG market has been growing over the last decade [16]. As a result, the comparative advantage is very significant to enhance RMG export to the global market. The Revealed Comparative Advantage (RCA) index ranking, first introduced by Balassa, is the most popular method for explaining the comparative advantages.

Figure 2 shows the Revealed Comparative Advantage (RCA) of the top ten RMG products of Bangladesh. This figure indicates the RCA of the top ten RMG products that have achieved stability from 2001 to 2012, but there is more fluctuation-NRCA is from 0.95 to 0.94 respectively-in the last three years from 2012 to 2015. After the US-GSP suspension, the RCA ranking has fallen gradually. Bangladesh and Cambodia accomplish the first and second position respectively in the world market in RCA ranking for the RMG products. On the other hand, China, Vietnam and Turkey have gradually fallen in the NRCA status in the world market. China has apparently left RMG production. It has the intention to develop capital-intensive production process.
Here, there is a great opportunity to increase own market share in global apparel market for Bangladesh and all other competitors and grasp up the renounced market share by China. Challenges like high-end productivity, properly utilizing lead time, quality production, favourable government policies like trade-friendly policies and environment, easing trade process are highly concerned matters. India has launched a specific target-wise trade policy, where they make an input out a mechanism to be in leading position crossing the Bangladesh and grasp the share of China from the world apparel market. Bangladesh has a great opportunity to be a strong competitor by using its available labour power. It is high time that proper steps are taken and measures on implementing modern technology in production, getting into the green industry, and comes up with more trade-friendly policies.

It can be evaluated that skipping Bangladesh from the Generalized System of Preferences (GSP) in the recent review by the US government has been going to affect the ready-made garment export of Bangladesh to the global market. On the other hand, other competing countries such as Cambodia, Sri Lanka, Pakistan and India have been increasing their trade volumes of RMG products to the USA market day by day. 


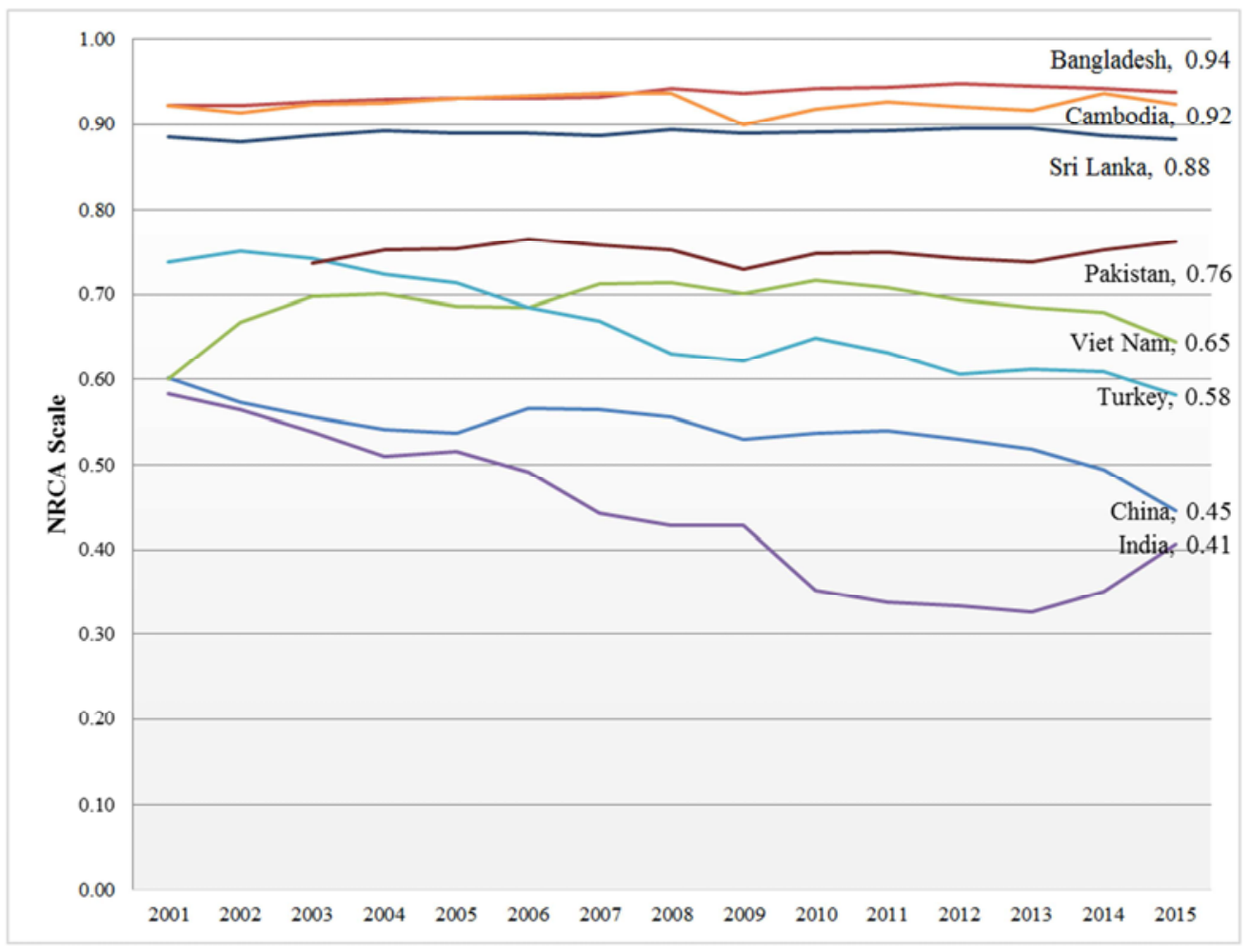

Source: ITC, Geneva and Authors' own calculation, 2016

Figure 2. RMG's Revealed Comparative Advantages (RCA) of the Competitors in the World.

\subsection{RMG Industry Competitiveness Between EU and USA Market}

The RMG industry of Bangladesh has expanded dramatically over the last three decades. Bangladesh RMG products are mainly exported to the United States of America as a single country and the European Union as a trade bloc. These two destinations account for more than 81 percent of country's total export earnings from garment products. The apparel sector alone accounts for almost 82 percent of Bangladesh's total export. A review of the garment industry shows that the availability of lower cost and standard quality products in Bangladesh are the two major strengths for Bangladesh to be very competitive in the global RMG market. The increase in production cost everywhere in the world is the main reason for the country's headway in this. Therefore, forgoing Bangladesh from the US-GSP facility in the recent review has negatively affected the competitiveness of the RMG sector of Bangladesh. This has become a major concern from the perspective of business strategy and export policy for the country. Figure 2 indicates that Bangladesh has the highest number of RCA rank of the RMG exports, which indicates a high competitiveness during 2001 to 2015.

However, a close look at the study outcomes shows that comparative advantage of Bangladesh has been highly concentrated around the basic ready-made garment products. After the Rana Plaza incidence, the NRCA value of the top ten RMG products at HS code 6-digit (61 and 62) of Bangladesh has shown a rising trend from 2001 to 2013.
Again, the trend of NRCA of RMG products of Bangladesh has declined after the US-GSP suspension from 2013 to 2015. Before the suspension of GSP, Bangladesh used to export nearly $\$ 36$ million worth of products (in the year 2012) under the scheme. The US-GSP is thus very significant to keep the good image for RMG business as well as to help to expand the RMG products of Bangladesh for new market exploration.

\section{Conclusion and Policy Recommendations}

In this paper, an attempt has been made to provide evidence on the pattern of comparative advantage of Bangladesh, as well as the other major competing countries for the top ten RMG products as indicated by the product composition of their exports to the USA and EU markets. After the GSP suspension, Bangladesh's export share to the US market has decreased from 6.01 to 5.68 percent, amounting to be US\$ 134.64 million as on 2014. The empirical findings from this paper suggest that Bangladesh has a comparative advantage over the other major competing countries in the USA and EU markets for the top ten RMG products Bangladesh exports to the global market. This result also shows that the average comparative advantage of Bangladesh RMG sector is better in the market of EU than on the USA.

It further appears that the extent of specialization and 
diversification of RMG exports depends on a variety of factors, including the level of technological development, natural resource endowment (e.g. cotton), international political diplomacy, destination countries' trade facilitation policies (GSP) and the effects of economic integration.

In line with the main focus on the US-GSP facilities, the comparative advantage of Bangladesh, as well as the other major competing countries, appears to lie on the influence of the trade policy of destination countries like the US-GSP suspension for Bangladesh's products to the USA market. Among these countries, raw materials and energy dominate trade facilitation activities. Indian textile policy comforts to increase its RMG export volume more than its other competitor countries, especially Bangladesh to the destinations like the USA and EU markets. As a result, the US-GSP status and a temporal textile policy of Bangladesh may have helped to increase Bangladesh's exports to the global market. It is expected that the recommendations provided based on the study findings would help for the revision of Bangladesh's political diplomacy, as well as the empirical policy metrics, for its RMG sector for increasing RMG export volume, GDP growth, employment opportunities and women empowerment, among others.

\section{References}

[1] Liesner, H. H. (1958), "The European Common Market and British Industry", Economic Journal, 68, 302-16

[2] Balassa, B. (1965). Trade liberalisation and "revealed" comparative advantage. The Manchester School, 33(2), 99123.

[3] Balassa, B. (1979). The changing pattern of comparative advantage in manufactured goods. The Review of Economics and statistics, 259-266.

[4] Balassa, B. (1977). Revealed' comparative advantage revisited: An analysis of relative export shares of the industrial countries, 1953-1971. The Manchester School, 45(4), 327-344.
[5] Salvatore, D. (2007). International Economics. Hoboken, New Jersey: John Wiley \& Sons, Inc.

[6] Shohibul, A. (2013). Revealed comparative advantage measure: ASEAN-China trade flows. Journal of Economics and Sustainable Development, 4(7), 136-145.

[7] Ministry of Finance. (2014). Bangladesh Economic Review. Dhaka: Bangladesh Government Press.

[8] Bangladesh Bank. (2015). Annual Report 2013 - 2014. Dhaka: Bangladesh Bank.

[9] Yeats, A. J. (1992). What do alternative measures of comparative advantage reveal about the composition of developing countries' exports. Indian Economic Review, 139154.

[10] Ahmad, N. (2013). Changing Revealed Comparative Advantage of Textile and Clothing Sector of Pakistan: Pre and Post Quota Analysis. Pakistan Journal of Commerce and Social Sciences, 7(3).

[11] Bastos, P., \& Cabral, M. (2007). The dynamics of international trade patterns. Review of World Economics, 143(3), 391-415.

[12] Hadzhiev, V. (2014). More on Measuring the Overall Revealed Comparative Advantage.

[13] Mohan Kathuria, L. (2013). Analyzing competitiveness of clothing export sector of India and Bangladesh: Dynamic revealed comparative advantage approach. Competitiveness Review: An International Business Journal, 23(2), 131-157.

[14] Bacchetta, M., Beverelli, C., Cadot, O., Fugazza, M., Grether, J. M., Helble, M. \& Piermartini, R. (2012). A practical guide to trade policy analysis. World Trade Organization.

[15] Laursen, K. (2000), Trade Specialisation, Technology and Economic Growth: Theory and Evidence from Advanced Countries, Cheltenham: Edward Elgar

[16] Rahman, M. H., \& Siddiqui, S. A. (2015). RMG: prospect of contribution in economy of Bangladesh. International Journal of Scientific and Research Publications, 5(9), 1-8. 